\title{
Evolutionary transition to freshwater by ancestral marine palaemonids: evidence from osmoregulation in a tide pool shrimp
}

\author{
Alessandra Augusto ${ }^{1}$, Adriana Silva Pinheiro ${ }^{2}$, Lewis Joel Greene ${ }^{3}$, \\ Helen Julie Laure ${ }^{3}$, John Campbell McNamara ${ }^{2, *}$ \\ ${ }^{1}$ Centro de Aquicultura, Universidade Estadual Paulista, Jaboticabal, SP 14870-810, Brazil \\ ${ }^{2}$ Departamento de Biologia, Faculdade de Filosofia, Ciências e Letras de Ribeirão Preto, Universidade de São Paulo, \\ Ribeirão Preto, SP 14040-901, Brazil \\ ${ }^{3}$ Centro de Química de Proteínas, Faculdade de Medicina, Universidade de São Paulo, Ribeirão Preto, SP 14051-040, Brazil
}

\begin{abstract}
The transition from marine/brackish waters to freshwater habitats constitutes a severe osmotic and ionic challenge, and successful invasion has demanded the selection of morphological, physiological, biochemical and behavioral adaptations. We evaluated short-term (1 to $12 \mathrm{~h}$ exposure) and long-term (5 d acclimation), anisosmotic extracellular (osmolality, $\left[\mathrm{Na}^{+}, \mathrm{Cl}^{-}\right]$) and long-term isosmotic intracellular osmoregulatory capability in Palaemon northropi, a neotropical intertidal shrimp. $P$. northropi survives well and osmo- and ionoregulates strongly during short- and long-term exposure to 5-45\% salinity, consistent with its rocky tide pool habitat subject to cyclic salinity fluctuations. Muscle total free amino acid (FAA) concentrations decreased by $63 \%$ in shrimp acclimated to $5 \%$ salinity, revealing a role in hypoosmotic cell volume regulation; this decrease is mainly a consequence of diminished glycine, arginine and proline. Total FAA contributed $31 \%$ to muscle intracellular osmolality at $20 \%$, an isosmotic salinity, and decreased to $13 \%$ after acclimation to $5 \%$. Gill and nerve tissue FAA concentrations remained unaltered. These tissue-specific responses reflect efficient anisosmotic and anisoionic extracellular regulatory mechanisms, and reveal the dependence of muscle tissue on intracellular osmotic effectors. FAA concentration is higher in $P$. northropi than in diadromous and hololimnetic palaemonids, confirming muscle FAA concentration as a good parameter to evaluate the degree of adaptation to dilute media. The osmoregulatory capability of $P$. northropi may reflect the potential physiological capacity of ancestral marine palaemonids to penetrate into dilute media, and reveals the importance of evaluating osmoregulatory processes in endeavors to comprehend the invasion of dilute media by ancestral marine crustaceans.
\end{abstract}

KEY WORDS: Freshwater invasion - Marine-freshwater transition - Physiological adaptation · Osmotic and ionic regulation $\cdot$ Free amino acids $\cdot$ Palaemonid shrimp $\cdot$ Palaemon northropi

Resale or republication not permitted without written consent of the publisher

\section{INTRODUCTION}

The invasion of freshwater by the decapod Crustacea began some 600 million years ago (Ruppert \& Barnes 1994), a process often inextricably associated with increasing terrestriality. To illustrate, some sesarminid (Schubart \& Diesel 1998, 1999) and ocypodidid (Thurman 2003) brachyurans occupy freshwater secondarily, having penetrated from the marine supralittoral into semiterrestrial riverbank habitats, using this medium for gill wetting, molting, larval release and refuge. Other taxa such as palaemonid shrimp, however, have taken a more direct route via brackish waters like coastal lagoons and estuaries, followed by penetration into freshwater habitats (Freire et al. 2003).

The interface between the marine and freshwater habitats presents an osmotic and ionic barrier that few crustacean taxa have been able to penetrate. While 
the extracellular body fluids of most marine species approximate seawater in composition and are essentially isosmotic and mainly isoionic with respect to $\mathrm{Na}^{+}$and $\mathrm{Cl}^{-}$, such ion concentrations are minimal in freshwater. Consequently, freshwater species must expend more energy on the anisosmotic and anisoionic regulatory mechanisms that maintain their steep osmotic and ionic gradients against the surrounding medium, sustaining their essential life processes. The successful invasion of dilute media includes the selection of favorable morphological (Taylor \& Taylor 1992, Freire \& McNamara 1995, Onken \& McNamara 2002), physiological (Péqueux 1995, Kirschner 2004, Weihrauch et al. 2004, Tsai \& Lin 2007, Freire et al. 2008) and biochemical (Leone et al. 2005, Mendonça et al. 2007) adaptations, and those ancestral crustaceans that surmounted this barrier evidently evolved efficient mechanisms of hyperosmotic and ionic regulation, allowing survival in such habitats (Schubart \& Diesel 1998, 1999).

The principal mechanisms of ionic and osmotic regulation in freshwater crustaceans include active salt absorption across the specialized gill epithelia (Lima et al. 1977, McNamara \& Lima 1997, McNamara \& Torres 1999, Weihrauch et al. 2004, Belli et al. 2009) and low water permeability that, together with the excretion of isosmotic or dilute urine by the antennal glands (Denne 1968, Augusto et al. 2007a), allows the anisoionic and anisosmotic regulation of hemolymph ions and water essential to optimal cell and organ metabolism (Freire et al. 2003, 2008). In estuarine or diadromous crustaceans that inhabit brackish or dilute media, a second mechanism, isosmotic intracellular regulation, adjusts cell volume by means of osmotic effectors like $\mathrm{K}^{+}$, small peptides and, particularly, free amino acids (FAA). Adjustment in the intra- and extracellular FAA pools depends on alterations in FAA synthesis and oxidation rates, shifts in flux equilibria across the cell membranes and/or changes in protein metabolism (Tan \& Choong 1981, Péqueux 1995). Further, tissue FAA concentrations can be used as good indicators of the recency of freshwater invasion, given their reduced concentration in freshwater crustaceans, compared to marine crustaceans (Potts \& Parry 1964, Mantel \& Farmer 1983, Augusto et al. 2007a,b).

Studies on the invasion of freshwater are sparse and are not well resolved with regard to subjacent physiological mechanisms. The transition to freshwater has occurred not only on a macroevolutionary scale, but also recently, continuing to the present day in many diadromous palaemonids, particularly within the genus Macrobrachium (Moreira et al. 1983, Jalihal et al. 1993, Pereira \& Garcia 1995, Freire et al. 2003, Murphy \& Austin 2005). Lee \& Bell (1999) suggest that freshwater invaders might originate more readily from ancestors that occupied habitats exhibiting ample temporal and/or spatial salinity ranges since broad salinity tolerance can develop under these circumstances. Additionally, diurnal or seasonal salinity fluctuations are important as these lesser time-scales determine acclimation response rates. Of particular interest in the study of the conquest of freshwater are intertidal species, confronted daily by notable, cyclic salinity fluctuations, and whose osmoregulatory abilities may still reflect those of ancestral species that invaded dilute media, offering an excellent opportunity to examine basal traits and physiological adaptation in progress. We hypothesize that the colonization of freshwater by the palaemonid shrimps may have come about by means of a brackish water ancestor frequently exposed to a wide salinity range. This ancestral species must have acquired osmotic and ionic regulatory capability in dilute media, which would furnish the sustaining adaptations requisite for the subsequent invasion of freshwater.

As an experimental model, we employ Palaemon northropi, an intertidal, palaemonid shrimp distributed from the Bermuda archipelago in Central America to Uruguay in southern South America (Holthuis 1952). This species inhabits rocky tide pools where it frequently confronts widely variable salinities as a function of tides, precipitation, evaporation and seasonal temperature variation. Here we evaluate the osmoregulatory physiology of $P$. northropi, the chief process underpinning the conquest of dilute media. We examine responses like survival, osmotic and ionic regulatory capability and muscle tissue hydration and a role for FAA in intracellular volume regulation in shrimp exposed to a wide salinity range, during both shortterm exposure (hours) such as might occur during a daily tidal cycle, and after long-term exposure (days) to examine adjustments in intracellular FAA titers.

\section{MATERIALS AND METHODS}

Specimens of the neotropical intertidal shrimp Palaemon northropi, measuring from 1.5 to $4.0 \mathrm{~cm}$ total length (modal length $3.0 \mathrm{~cm}, \mathrm{~N} \approx 600$ ), were collected at low tide from tidal pools on the rocky shores of Barequeçaba and Guaecá beaches near São Sebastião on the northern coast of São Paulo State, Brazil $\left(23^{\circ} 47^{\prime} 32^{\prime \prime} \mathrm{S}, 45^{\circ} 35^{\prime} 54^{\prime \prime} \mathrm{W}\right)$. Salinity and temperature at the collection sites varied significantly $(\mathrm{p}<0.001)$, ranging from 3 to $33 \%$ and 24 to $31^{\circ} \mathrm{C}$, respectively, both parameters dependent on pool location on the shore.

In the laboratory, shrimp were held in $60 \mathrm{l}$ plastic tanks containing aerated seawater from the collection sites for $3 \mathrm{~d}$ prior to beginning experiments. Holding 
salinity was 31 to $33 \%$, stocking density was 21 ind. ${ }^{-1}$ and water temperature was maintained at $\sim 23^{\circ} \mathrm{C}$. The shrimp were fed on alternate days in the evening with fragments of fish muscle and checked daily in the morning for excess. Seawater was changed every 2 to 3 d when necessary, evaluated by accompanying water transparency.

To estimate the approximate lethal salinity limit, 3 groups of 10 shrimp each were directly exposed for a $10 \mathrm{~d}$ period to experimental saline media of $<0.5$ (freshwater), 1, 1.5, 2, 5, 20 or 45\% salinity. Adult Palaemon northropi survived $<2 \mathrm{~h}$ after direct transfer from seawater to fresh $(<0.5 \%$ ) or brackish $(1 \%)$ water. However, at $1.5 \%$ and above $(5,20$ and $45 \%$ ), all shrimp survived for at least $10 \mathrm{~d}$. Subsequent experiments were based on these findings.

To examine the effect of acute exposure to saline media on anisosmotic extracellular osmotic and ionic regulatory capability and on tissue hydration, groups of 12 to 13 intermolt shrimp were exposed to salinities of 5,20 or $50 \%$ for 1,6 or $12 \mathrm{~h}$ to simulate a tidal cycle. To evaluate the effect of long-term exposure to saline media on osmotic and ionic regulatory ability, isosmotic intracellular regulatory capacity and tissue hydration, groups of 30 intermolt shrimp were directly exposed to 5, 20 or $45 \%$ salinity for $5 \mathrm{~d}$. Shrimp for these analyses measured 3 to $4 \mathrm{~cm}$ total length. Saline media ( $<0.5$ to $20 \%$ ) were prepared by diluting seawater from the collection sites with freshwater or by diluting the first thaw of frozen seawater (for 45 and $50 \%$ ), and were verified using a hand-held optical refractometer (Model 10419, American Optical).

After each exposure period, hemolymph samples were taken from the pericardial region located at the dorsal/posterior margin of the cephalothorax using an insulin syringe coupled to a \#25-8 needle. Each pooled hemolymph sample $(\sim 50 \mu l)$ consisted of the hemolymph from 4 to 5 individual shrimp. Hemolymph osmolality was measured in 10- $\mu$ l samples using a vapor pressure osmometer (Model 5500, Wescor). Hemolymph $\mathrm{Na}^{+}$concentration was measured by atomic absorption spectrophotometry (Model 932AA, GBC Scientific Equipment) in 10- $\mu$ l hemolymph samples diluted 1:15000 in distilled water for shrimp exposed to $5 \%$; $1: 15000$ or $1: 25000$ for those exposed to 20 and $35 \%$; and 1:20000 or 1:50000 for those exposed to 45 and $50 \%$. Hemolymph $\mathrm{Cl}^{-}$concentration was measured in 10- $\mu$ l hemolymph samples using a microtitrator (Model E485, Metrohm AG), employing mercuric nitrate as the titrant and s-diphenylcarbazone as the indicator (Schales \& Schales 1941).

The isosmotic and isoionic points were calculated by solving quadratic equations produced from the equations for the hemolymph/external medium isosmotic or isoionic lines $(y=\mathrm{a}+\mathrm{bx})$ and the respective second order polynomial equations $\left(y=a x^{2}+b x+c\right)$ that describe the function between hemolymph osmolality or ionic concentration and that of the external medium. Resolution of these quadratic equations for $y=0$, i.e. the intercepts (real roots) of the 2 equations, provides the respective isosmotic or ionic points. Osmotic and ionic regulatory capabilities are expressed as the ratio of variation in hemolymph osmotic or ionic concentration $\left(\Delta\right.$ hemolymph mOsm $\mathrm{kg}^{-1} \mathrm{H}_{2} \mathrm{O}$ or mmol $\mathrm{l}^{-1} \mathrm{Na}^{+}$ and $\mathrm{Cl}^{-}$) as a function of variation in the osmotic or ionic concentration of the external medium from the respective values in 5 and $45 \%$ salinity. A ratio of 1 indicates no regulation; values close to 0 indicate excellent regulatory capability (Freire et al. 2003).

To identify and quantify tissue FAA, muscle tissue samples ( $50 \mathrm{mg}$ ) were taken from the abdominal muscle, free of nerve cord and intestine. Nerve tissue samples consisted of the ventral nerve cord and optic, thoracic and supraesophageal ganglia ( 10 mg). The gill tissue sample consisted of gill pairs 6 to $8(\sim 2 \mathrm{mg})$. The fresh tissue samples were carefully weighed after standard blotting $( \pm 10 \mu \mathrm{g}$ precision, Ohaus APD 250 electronic balance), oven-dried at $60{ }^{\circ} \mathrm{C}$ for $24 \mathrm{~h}$ and quickly reweighed. Tissue hydration (\%) was calculated as: [(fresh weight - dry weight)/fresh weight] $\times 100$.

For FAA analyses, the dried tissue samples were homogenized in distilled water, protein being precipitated with $80 \%$ ethanol (v/v). An internal standard of $6.24 \mathrm{nmol} \alpha$-aminobutyric acid was added and the samples were derivatized with triethylamine and phenylisothiocyanate, forming FAA/phenylthiocarbamil derivatives (Bidlingmeyer et al. 1987). The individual FAA were identified and quantified by HPLC (Milton Roy) using a Picotag C18 Column (Waters Corporation) according to Freire et al. (1995) and Augusto et al. (2007a). FAA contribution to intracellular osmolality was estimated by converting the total FAA concentration obtained in nmol $\mathrm{mg}^{-1}$ dry weight (DW) to mmol kg-1 fresh weight, and assuming osmotic equilibrium between the intra- and extracellular media and negligible hemolymph FAA titers in a $30 \%$ hemolymph space for muscle and nerve tissue (50\% for gill tissue).

The effects of exposure time to the different salinities on hemolymph osmolality, $\mathrm{Na}^{+}$and $\mathrm{Cl}^{-}$concentrations, tissue hydration and FAA titers were evaluated using 1- or 2-way ANOVA (salinity, salinity/time and salinity/tissue) followed by the Student-NewmanKeuls (SNK) multiple means test to locate statistically significant groups. All statistical analyses were performed after ascertaining normality of distribution and equality of variance using the Sigma Stat 2.03 software package (SPSS), employing a minimum significance level of $\mathrm{p}=0.05$. Data are expressed in the text as mean $\pm \mathrm{SE}$. 


\section{RESULTS}

\section{Osmotic and ionic regulation}

Hemolymph osmolality and $\mathrm{Na}^{+}$and $\mathrm{Cl}^{-}$concentrations during long-term ( $5 \mathrm{~d}$ ) acclimation and short-term (1 to $12 \mathrm{~h}$ ) exposure of Palaemon northropi to a wide salinity range are provided in Figs. 1 to 3.

Palaemon northropi is a strong long-term hyper-/ hypo-osmoregulator with an osmoregulatory capability ( $\Delta$ hemolymph osmolality/ $\Delta$ medium osmolality) of 0.32 and an isosmotic point of 566 mOsm kg ${ }^{-1} \mathrm{H}_{2} \mathrm{O}$ (18.3\%o) (Fig. 1A). Control shrimp held at 35\% maintained a hemolymph osmolality of $714 \pm 7 \mathrm{mOsm} \mathrm{kg}^{-1}$ $\mathrm{H}_{2} \mathrm{O}$, decreasing to $599 \pm 12$ in $20 \%$ ond to $548 \pm 12$ in $5 \%$; osmolality increased to $948 \pm 31$ mOsm kg ${ }^{-1} \mathrm{H}_{2} \mathrm{O}$ on acclimation to $45 \%$ (Fig. 1A).

During short-term exposure of shrimp initially held at $35 \%$ (Fig. 1B), hemolymph osmolality remained unchanged in those exposed to $20 \%$, but decreased moderately after $6 \mathrm{~h}\left(555 \pm 7 \mathrm{mOsm} \mathrm{kg}{ }^{-1} \mathrm{H}_{2} \mathrm{O}\right)$ and $12 \mathrm{~h}(605 \pm$

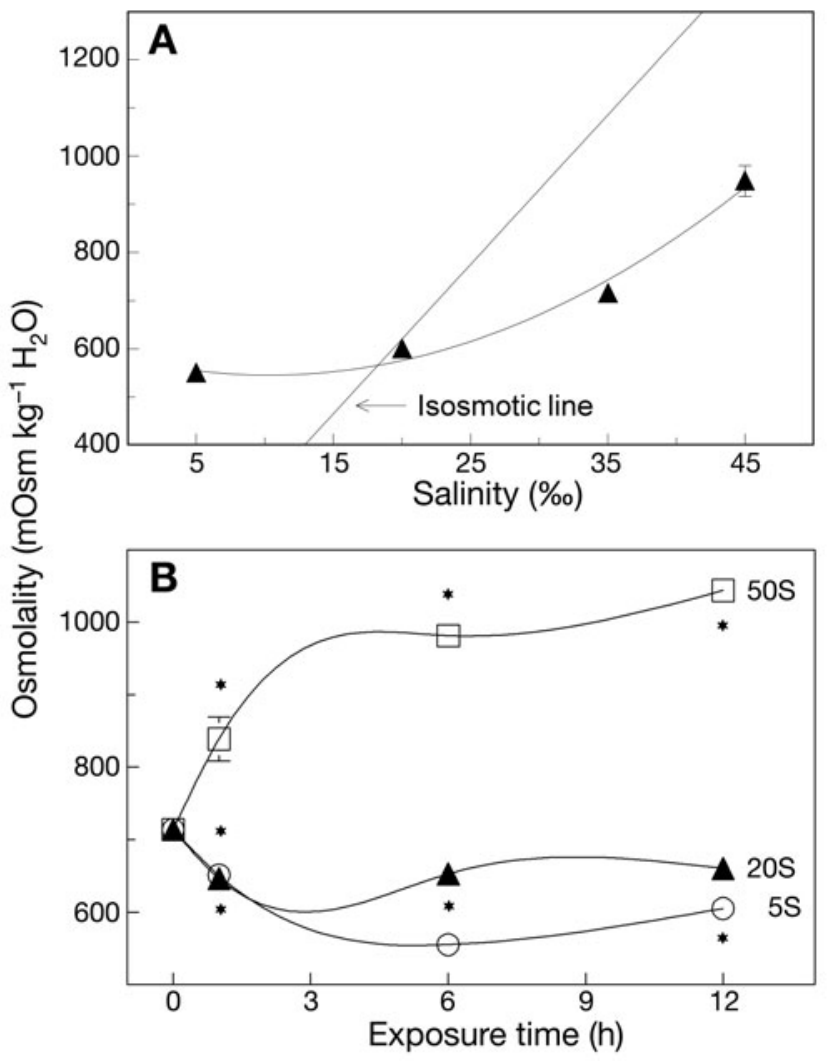

Fig. 1. Palaemon northropi. (A) Hemolymph osmoregulatory capability after $5 \mathrm{~d}$ acclimation to 5 to $45 \%$ salinity range. All means are significantly different from each other $(0.001<\mathrm{p} \leq$ $0.04, y=0.32 x^{2}-6.72 x+580.13, \mathrm{R}^{2}=0.98$ ). (B) Changes in hemolymph osmolality during exposure from $35 \%$ o (time $=0 \mathrm{~h}$ ) to hypo- (5 and $20 \%$ ) and hyperosmotic $(50 \%)$ media. Values are mean $\pm \mathrm{SE}(\mathrm{N}=6)$. ${ }^{*}$ Significantly different from preceding value $(\mathrm{p} \leq 0.05)$
$15 \mathrm{mOsm} \mathrm{kg} \mathrm{k}_{2}^{-1} \mathrm{O}$ ) in shrimp exposed to $5 \%$. On exposure to $50 \%$, osmolality increased sharply to $981 \pm$ 2 mOsm kg-1 $\mathrm{H}_{2} \mathrm{O}$ after $6 \mathrm{~h}$ and to $1044 \pm 17 \mathrm{mOsm} \mathrm{kg}^{-1}$ $\mathrm{H}_{2} \mathrm{O}$ by $12 \mathrm{~h}$ (Fig. 1A). Hemolymph osmolality was hyper-regulated in 5 and $20 \%$ and hyporegulated in $50 \%$ during all short-term exposures; after 1, 6 and $12 \mathrm{~h}$ exposure to these media, isosmotic points gradually increased (655 mOsm kg ${ }^{-1} \mathrm{H}_{2} \mathrm{O}$ [22.3\%o], $659 \mathrm{mOsm} \mathrm{kg}^{-1}$ $\mathrm{H}_{2} \mathrm{O}$ [22.5\%] and $662 \mathrm{mOsm} \mathrm{kg} \mathrm{k}^{-1} \mathrm{H}_{2} \mathrm{O}$ [22.6\%o], respectively), while osmoregulatory capabilities decreased (0.14, 0.32 and 0.33 , respectively).

Hemolymph $\left[\mathrm{Na}^{+}\right]$in shrimp held for $5 \mathrm{~d}$ at $35 \%$ was $201 \pm 12 \mathrm{mM}$ and remained unchanged after transfer to $5(249 \pm 32), 20(221 \pm 20)$ or $45 \%$ o $\left(268 \pm 4 \mathrm{mM} \mathrm{Na}^{+}\right)$. $\left[\mathrm{Na}^{+}\right]$was hyper-regulated up to the isoionic point at $201 \mathrm{mM}(14.3 \%$ ) and was strongly hyporegulated at higher salinities (Fig. 2A). $\mathrm{Na}^{+}$regulatory capability was 0.03 .

During short-term exposure of shrimp kept at 35\%, hemolymph $\left[\mathrm{Na}^{+}\right]$increased markedly after $1 \mathrm{~h}$ at all salinities $\left(5,20\right.$ or $50 \%$ ) (Fig. 2B). In $20 \%$, $\left[\mathrm{Na}^{+}\right]$rapidly

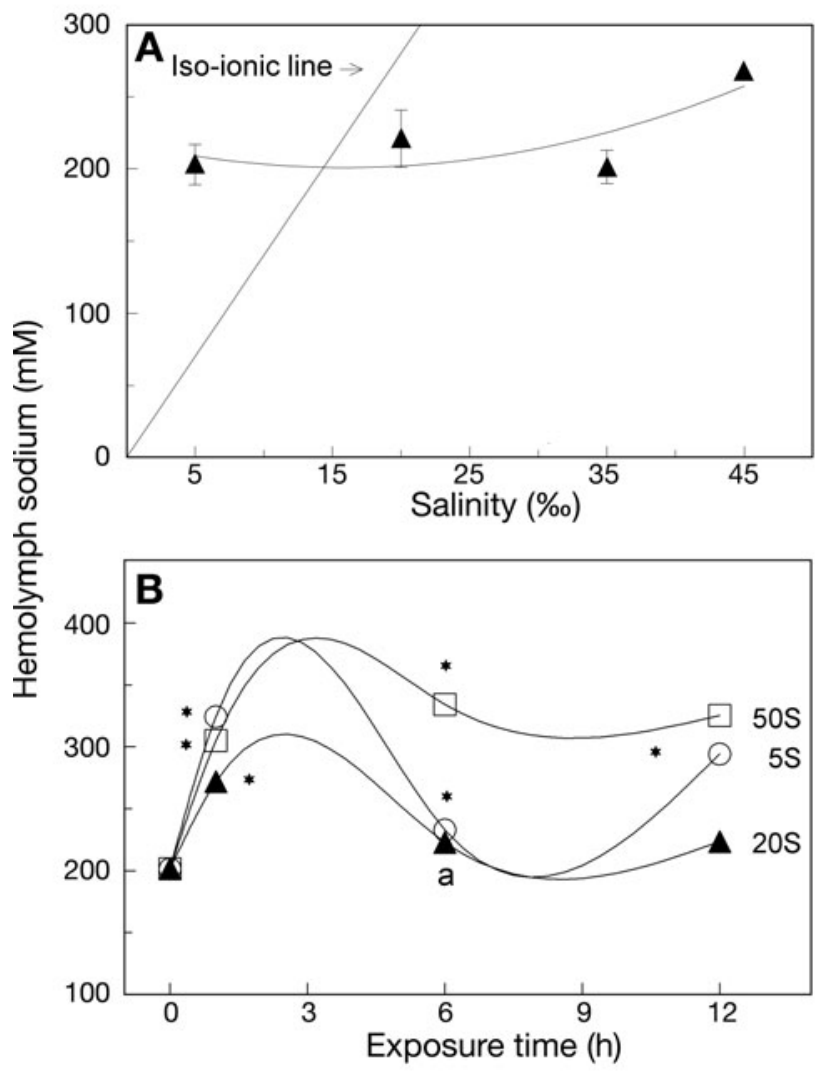

Fig. 2. Palaemon northropi. (A) Hemolymph $\mathrm{Na}^{+}$concentration after $5 \mathrm{~d}$ acclimation to 5 to $45 \%$ salinity. [ $\left.\mathrm{Na}^{+}\right]$is unaffected by salinity $\left(\mathrm{p}=0.228, y=0.07 \mathrm{x}^{2}-2.13 x+217.94\right.$, $\mathrm{R}^{2}=0.63$ ). (B) Changes in hemolymph $\left[\mathrm{Na}^{+}\right]$during exposure to hypo- (5 and 20\%) and hyperosmotic (50\%) media. Values are mean $\pm \mathrm{SE}(\mathrm{N}=6)$. ${ }^{*}$ Significantly different from preceding value $(\mathrm{p} \leq 0.05) ;{ }^{a}$ not significantly different from time $=0 \mathrm{~h}$ 
decreased to initial values within $6 \mathrm{~h}$, but remained significantly elevated after $12 \mathrm{~h}$ at $50 \%$; however, in $5 \%$, after a decrease at $6 \mathrm{~h},\left[\mathrm{Na}^{+}\right]$increased after $12 \mathrm{~h}$ exposure. Hemolymph $\left[\mathrm{Na}^{+}\right]$was hyper-regulated in $5 \%$ for all short-term exposures, and hyporegulated in all other salinities. Isoionic points after 1, 6 and $12 \mathrm{~h}$ were $273(19.9 \%), 231$ (16.9\%) and $236 \mathrm{mM} \mathrm{Na}^{+}$ $\left(17.2 \%\right.$ ), respectively. $\mathrm{Na}^{+}$regulatory capability at 1,6 and $12 \mathrm{~h}$ was $0,0.16$ and 0.05 , respectively.

Hemolymph $\left[\mathrm{Cl}^{-}\right]$in shrimp held at $35 \%$ o was $283 \pm$ $13 \mathrm{mM}$, decreasing slightly after $5 \mathrm{~d}$ exposure to $20 \%$ $(247 \pm 9)$; in 5 and $45 \%$, concentrations decreased $\left(209 \pm 1 \mathrm{mM} \mathrm{Cl}^{-}\right)$or increased $\left(367 \pm 9 \mathrm{mM} \mathrm{Cl}^{-}\right)$, respectively (Fig. 3A). $\left[\mathrm{Cl}^{-}\right]$was hyper-regulated up to the isoionic point at $217 \mathrm{mM}(13.6 \%$ ) and strongly hyporegulated at higher salinities. $\left[\mathrm{Cl}^{-}\right]$regulatory capability was 0.25 .

During short-term salinity exposure (1, 6 and $12 \mathrm{~h}$ ) (Fig. 3B), hemolymph $\left[\mathrm{Cl}^{-}\right]$was unchanged in $20 \%$, but increased steadily with time in $50 \%$. In $5 \%$, $\left[\mathrm{Cl}^{-}\right]$ decreased sharply after 1 and $6 \mathrm{~h}$, recovering initial values by $\left.12 \mathrm{~h} . \mathrm{CCl}^{-}\right]$was hyper-regulated at $5 \%$ and strongly hyporegulated at all other salinities. The isoionic points after 1, 6 and $12 \mathrm{~h}$ were 270 (17\%o), 278 (17.4\%o) and $266 \mathrm{mM}\left[\mathrm{Cl}^{-}\right]$(16.6\%o), respectively, while $\left[\mathrm{Cl}^{-}\right]$regulatory capabilities progressively decreased $(0.15,0.28$ and 0.3 , respectively).

\section{Tissue hydration and FAA concentrations}

There was no change in muscle tissue hydration $(84.6 \%$ at $35 \%$, time $=0)$ in shrimp exposed to $5 \%$ between 1 and $24 \mathrm{~h}$ (Fig. 4). In 20\%, hydration increased to a maximum within $1 \mathrm{~h}$, declining to seawater values after $6 \mathrm{~h}$. In $50 \%$, hydration rapidly decreased within $1 \mathrm{~h}$, reaching a minimum by $6 \mathrm{~h}$ which was sustained up to $24 \mathrm{~h}$. However, by $120 \mathrm{~h}$, muscle hydration was similar at all salinities (82\%), although less than initial values in seawater. Gill and nerve tissue hydration in Palaemon northropi held at $20 \%$ was also $~ 84 \%$, unchanged after 5 d acclimation to 5 or $45 \%$ salinity.

Total FAA concentrations in the muscle tissue alone decreased by $65 \%$, from $143 \pm 12$ to $53 \pm 6 \mathrm{mmol} \mathrm{kg}^{-1}$ wet weight (WW) (Fig. 5A), after acclimation from 20 to $5 \%$ for $5 \mathrm{~d}$. In the hemolymph, total FAA increased by $150 \%$, from $4.6 \pm 1.2 \mathrm{mmol} \mathrm{l}^{-1}$ at $20 \%$ to $11.5 \pm$ $2.0 \mathrm{mmol} \mathrm{l}^{-1}$ in $5 \%$ after $5 \mathrm{~d}$ (Fig. 5B). There were no changes in total FAA in the gill and nerve tissues after acclimation to any salinity (Fig. 5A).

The decrease in muscle total FAA on acclimation to $5 \%$ is mainly a consequence of diminished glycine $(-71 \%)$, arginine $(-95 \%)$ and proline (-66\%) (Table 1$)$. In the hemolymph, the increase in total FAA concen-
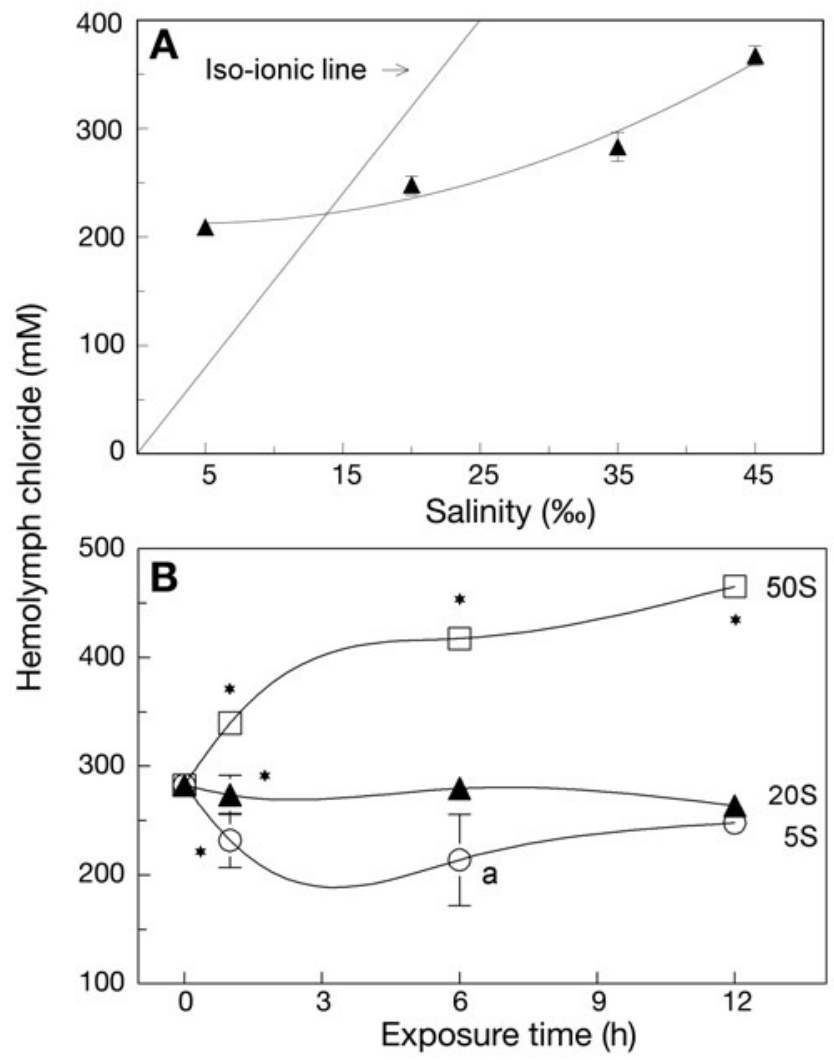

Fig. 3. Palaemon northropi. (A) Hemolymph $\mathrm{Cl}^{-}$concentration after $5 \mathrm{~d}$ acclimation to 5 to $45 \%$ salinity. All means are significantly different from each other $\left(0.001<\mathrm{p} \leq 0.002, y=0.09 x^{2}\right.$ $\left.-0.65 x+213.69, \mathrm{R}^{2}=0.97\right)$. (B) Changes in hemolymph $\left[\mathrm{Cl}^{-}\right]$ during exposure to hypo- (5 and $20 \%$ ) and hyperosmotic $(50 \%)$ media. Values are mean $\pm \mathrm{SE}(\mathrm{N}=6) .{ }^{*}$ Significantly different from preceding value; ${ }^{\mathrm{a}}$ significantly different from control (time $=0 \mathrm{~h})(\mathrm{p} \leq 0.05)$

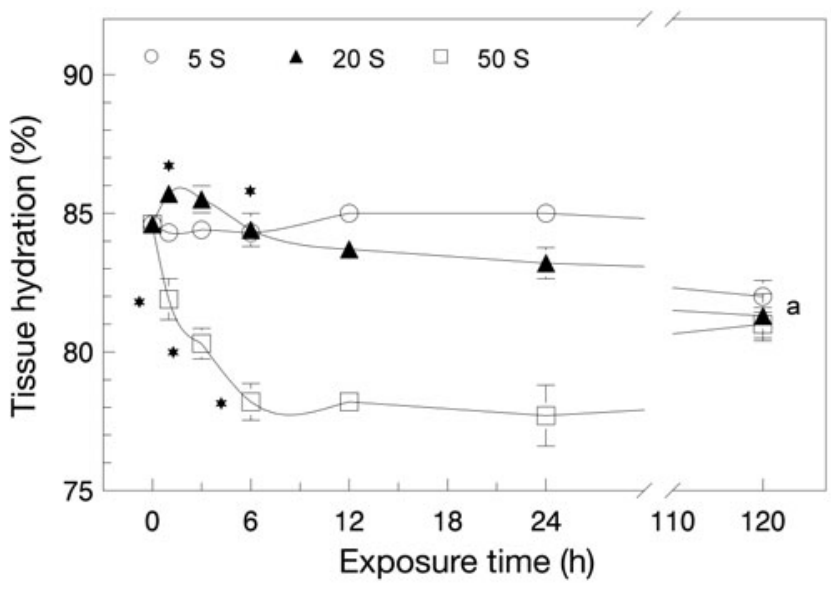

Fig. 4. Palaemon northropi. Effect of direct acclimation to salinities of 5,20 or $50 \%$ on muscle tissue hydration. Values

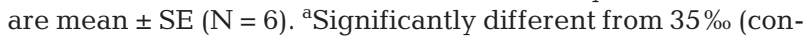
trol, time $=0 \mathrm{~h}$ ); ${ }^{*}$ significantly different from preceding value ( $\mathrm{p} \leq 0.05$ ) 

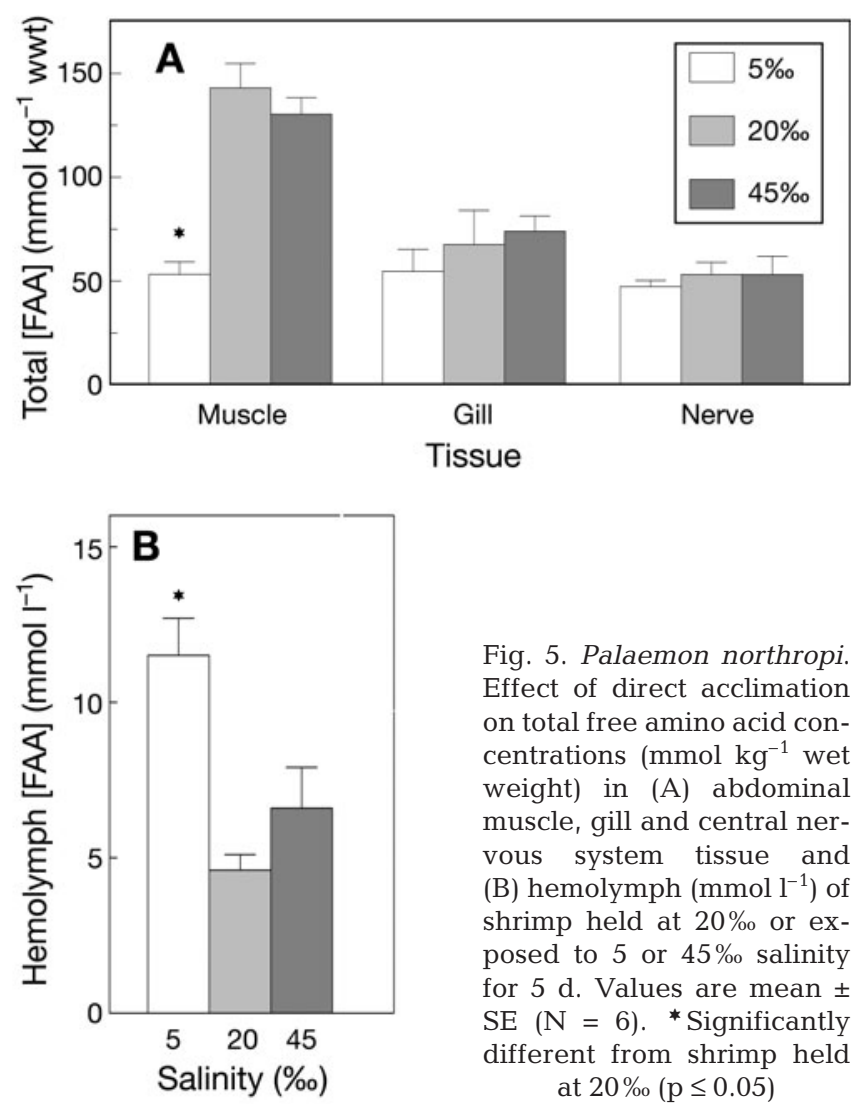

tration after exposure to $5 \%$ is mainly due to alanine $(+384 \%)$ and proline $(+216 \%)$ (Table 1$)$.

Total FAA contribution to intracellular osmolality decreased in the muscle tissue alone, from $31 \%$ in shrimp at $20 \%$, to 13 and $18 \%$ in 5 and $45 \%$, respectively. The contribution of FAA to intracellular osmolality in gill $(14 \%)$ and nerve tissue $(10 \%)$ was similar at all 3 salinities.

\section{DISCUSSION}

Many intertidal marine and estuarine crustaceans confront cyclic fluctuations in salinity, temperature and oxygen concentration, and exhibit notable acclimatory capability (Mantel \& Farmer 1983). A case in point, Palaemon northropi survives remarkably well in media ranging from 1.5 to $45 \%$ salinity, and for up to $24 \mathrm{~h}$ in $50 \%$, much like $P$. affinis (Kirkpatrick \& Jones 1985), P. longirostris (Campbell \& Jones 1989) and P. pandaliformis (Freire et al. 2003). Such survival ability, underpinned by effective hyper-/hypo-osmoregulatory mechanisms, may have allowed the penetration of ancestral euryhaline marine or estuarine palaemonids into brackish and fresh water, a considerable advantage compared to stenohaline marine decapods, confined to a restricted salinity range. Marine and brackish water palaemonids also show fairly similar osmoregulatory capabilities with isosmotic points close to their modal salinities a little above the middle of their osmoregulatory ranges (Table 2), a characteristic typical of species inhabiting variable salinity environments (Parry 1954, Denne 1968, Spaargaren 1972, Kirkpatrick \& Jones 1985, Morris et al. 1988, González-Ortegón et al. 2006).

Although Palaemon northropi cannot absorb salt against fresh $(<0.5 \%$ ) or very dilute brackish $(1.0 \%)$ water, succumbing within a few hours (see estimating lethal limits in 'Materials and methods'), it strongly hyper-/hyporegulates hemolymph osmolality during both direct, short-term exposure and after $5 \mathrm{~d}$ acclimation at 5 to $45 \%$ salinity. Such regulatory capacity is consistent with the species' occurrence in rocky tide pools where the measured summer salinity ranges from 3 to $33 \%$ (see 'Materials and methods') as a function of tides, evaporation and precipitation. Hemolymph $\mathrm{Na}^{+}$and $\mathrm{Cl}^{-}$concentrations are also efficiently hyper-/hyporegulated during short-term exposure and

Table 1. Palaemon northropi. Principal individual and total free amino acid concentrations in abdominal muscle, gill and nerve tissue (mmol kg${ }^{-1}$ wet weight) and hemolymph $\left(\mu \mathrm{mol} \mathrm{l}^{-1}\right.$ ) of the intertidal shrimp P. northropi held in $20 \%$ or exposed to 5 or $45 \%$ salinity for $5 \mathrm{~d}$. Data are mean $\pm \mathrm{SE}(\mathrm{N}=6)$. " Significantly different from same tissue in $20 \%$ o $(\mathrm{p}<0.05$, 1 -way ANOVA, Student-Newman-Keuls multiple means test). nd: not determined

\begin{tabular}{|lcccccccc|}
\hline Tissue & Salinity $(\%)$ & Glycine & Taurine & Arginine & Alanine & Proline & Other FAA & Total \\
\hline Muscle & 5 & $19.5 \pm 1.2^{*}$ & $7.8 \pm 0.5$ & $0.6 \pm 0.2^{*}$ & $3.5 \pm 0.4$ & $5.0 \pm 0.7^{*}$ & 55 & $53.3 \pm 6.0^{*}$ \\
& 20 & $68.0 \pm 16.8$ & $18.4 \pm 5.2$ & $12.5 \pm 1.3$ & $6.9 \pm 2.1$ & $14.6 \pm 8.1$ & 22 & $143 \pm 12.0$ \\
Gill & 45 & $65.3 \pm 4.1$ & $14.7 \pm 0.8$ & $13.6 \pm 0.2$ & $11.2 \pm 1.7$ & $9.7 \pm 5.9$ & 15 & $130.3 \pm 7.5$ \\
& 5 & $4.7 \pm 1.1$ & nd & $13.5 \pm 2.7$ & $9.0 \pm 1.8$ & $8.4 \pm 1.5$ & 26.7 & $54.7 \pm 10.5$ \\
& 20 & $16.4 \pm 1.6$ & nd & $17.9 \pm 4.3$ & $6.4 \pm 1.5$ & $5.0 \pm 0.9$ & 21.9 & $67.6 \pm 16.4$ \\
Nerve & 45 & $25.8 \pm 1.7$ & nd & $12.3 \pm 1.7$ & $8.2 \pm 0.8$ & $7.3 \pm 1.3$ & 20.4 & $74 \pm 7.3$ \\
& 5 & $4.1 \pm 0.3$ & $16.6 \pm 0.04$ & nd & $5.3 \pm 0.3$ & $5.9 \pm 0.1$ & 15.5 & $47.4 \pm 2.8$ \\
Hemolymph & 5 & $4.9 \pm 0.6$ & $12.8 \pm 1.5$ & $0.4 \pm 0.1$ & $5.8 \pm 0.6$ & $5.2 \pm 0.5$ & 24 & $53.1 \pm 5.8$ \\
& 20 & $7.0 \pm 1.2$ & $11.5 \pm 2.0$ & nd & $9.9 \pm 1.7^{*}$ & $11.1 \pm 1.9^{*}$ & 13.6 & $53.1 \pm 8.8$ \\
& 20 & $1435.5 \pm 54.5$ & $838.5 \pm 11.7$ & $48.5 \pm 4.8$ & $347.1 \pm 120.2$ & $510.7 \pm 191.3$ & 1426.7 & $4607 \pm 1169$ \\
& 45 & $1879.2 \pm 373.1$ & $664.8 \pm 99.4$ & $242.1 \pm 50.5$ & $956.1 \pm 203.9$ & $890.3 \pm 163.6$ & 1964.5 & $6597 \pm 1321$ \\
\hline
\end{tabular}


Table 2. Species, predominant biotope and hemolymph osmolality (at modal salinity indicated) and isosmotic point (both in Osm kg $\mathrm{kg}^{-1} \mathrm{H}_{2} \mathrm{O}$ ) for palaemonid shrimp from marine, brackish or freshwater environments. Hemolymph osmolality and isosmotic points clearly decline with occupation of dilute media among brackish water Palaemon and Palaemonetes, as also seen within brackish water, diadromous and hololimnetic Macrobrachium species

\begin{tabular}{|lcccl|}
\hline Species & Predominant biotope & $\begin{array}{c}\text { Hemolymph } \\
\text { osmolality }\end{array}$ & $\begin{array}{c}\text { Hemolymph } \\
\text { isosmotic point }\end{array}$ & Source \\
\hline Palaemon serratus & Marine/brackish & $770(25 \%)$ & 685 & Parry (1954) \\
Palaemon affinis & Marine/brackish & $750(20 \%)$ & 629 & Kirkpatrick \& Jones (1985) \\
Palaemon macrodactylus & Brackish & $725(23 \%)$ & 657 & Born (1968) \\
Palaemonetes varians & Marine/brackish & $620(22 \%)$ & 602 & Potts \& Parry (1964) \\
Palaemon northropi & Marine/intertidal & $599(20 \%)$ & 566 & Present study \\
Palaemon longirostris & Brackish & $573(17 \%)$ & 579 & González-Ortegón et al. (2006) \\
Palaemonetes pugio & Brackish & $550(17 \%)$ & 465 & Roesljadi et al. (1976) \\
Palaemon pandaliformis & Brackish & $450(25 \%)$ & 364 & Freire et al. (2003) \\
Palaemonetes argentinus & Brackish/freshwater & $410(1 \%)$ & 600 & Charmantier \& Anger (1999) \\
Macrobrachium equidens & Brackish & $555(29 \%)$ & 492 & Denne (1968) \\
Macrobrachium rosenbergii & Brackish/freshwater & $480(<0.5 \%)$ & 520 & Sandifer et al. (1975) \\
Macrobrachium acanthurus & Brackish/freshwater & $440(<0.5 \%)$ & 640 & Moreira et al. (1983) \\
Macrobrachium amazonicum & Freshwater (diadromous) & $403(<0.5 \%)$ & 602 & Augusto et al. (2007a) \\
Macrobrachium potiuna & Freshwater (hololimnetic) & $418(<0.5 \%)$ & 562 & Freire et al. (2003) \\
Macrobrachium brasiliense & Freshwater (hololimnetic) & $412(<0.5 \%)$ & 521 & Freire et al. (2003) \\
Macrobrachium olfersi & Freshwater (diadromous) & $336(<0.5 \%)$ & 428 & Freire et al. (2003) \\
Macrobrachium nipponense & Freshwater (hololimnetic) & $330(<0.5 \%)$ & 450 & Wang et al. (2004) \\
\hline
\end{tabular}

acclimation: $\mathrm{Na}^{+}$and $\mathrm{Cl}^{-}$increase after $12 \mathrm{~h}$ exposure to $50 \%$ from $35 \%$, such as might occur during evaporation at low tide. However, hemolymph $\left[\mathrm{Na}^{+}\right]$is unchanged after $5 \mathrm{~d}$ acclimation at 5, 20 or $45 \%$, while $\left[\mathrm{Cl}^{-}\right]$increased modestly with increasing salinity, inferring uncoupled regulatory mechanisms for these ions. Such osmoregulatory characteristics suggest that $P$. northropi is well adapted to fluctuating salinities, and its hyper-/hyporegulatory capability reflects a pattern typical of brackish water palaemonids (cf. GonzálezOrtegón et al. 2006). Conspicuously, however, very few Palaemon species actually inhabit freshwater: P. paucidens, a salt-tolerant (30\%), semi-hololimnetic, Indo-West Pacific species, is the only documented example (Fidhiany et al. 1991). Thus osmoregulatory capacity within the genus Palaemon may reflect the potential physiological capability of ancestral marine palaemonids to penetrate dilute media, characteristics that appear to have been lost during the subsequent radiation of diadromous and hololimnetic species into the freshwater biotope.

Crustacean cells, when exposed in vivo to hypo- or hyperosmotic media, do not simply swell or shrink like good osmometers, but rather recover their volume during a slow readjustment period. The overall volume regulation mechanism consists of a rapid phase limiting cell swelling or shrinkage, followed by a slower phase of volume readjustment (Gilles \& Péqueux 1981). In Palaemon northropi, muscle water contents are identical after $5 \mathrm{~d}$ acclimation to 5, 20 or $45 \%$; however, during short-term exposure to $20 \%$, tissue water increased very briefly and transiently $(3 \mathrm{~h})$, but de- creased notably and persistently (up to $24 \mathrm{~h}$ ) in $50 \%$, revealing much better regulation in hyposmotic than in hyperosmotic media, attesting to a notable capability to withstand dilute media at the tissue level. The efficient regulation of tissue hydration after acclimation is consistent with life in an unstable environment and constitutes an effective mechanism of osmotic regulation.

FAA are important intracellular osmotic effectors in crustaceans and many other organisms (Edwards 1982, Biagini et al. 2000, Frick \& Wright 2002, McNamara et al. 2004, Augusto et al. 2007a,b). Such regulation is a slow, temporally asymmetrical process occurring within $24 \mathrm{~h}$ of exposure to hypoosmotic media but requiring several days in hyperosmotic media (Gilles \& Péqueux 1983). Tissue total FAA concentrations also constitute a useful parameter to evaluate the degree of adaptation to dilute media (Potts \& Parry 1964), since they are 2- to 4-fold greater in marine compared to freshwater species. FAA decrease by $63 \%$ in muscle tissue of Palaemon northropi acclimated to $5 \%$, revealing a role in hypoosmotic cell volume regulation; however, gill and nerve tissues did not respond. The effective contribution of total FAA to intracellular osmolality subsequent to alteration in hemolymph osmolality also decreased to $13 \%$ in muscle tissue after exposure to $5 \%$ o compared to shrimp held at 20\% (31\% contribution). Such tissue-specific responses evidently reflect the efficient hemolymph osmotic and ionoregulatory mechanisms and reveal the dependence of muscle tissue on intracellular osmotic effectors like FAA. This response is consistent with the regulatory physiology 
of a species that inhabits rocky tide pools and is submitted daily to widely varying salinities. In species invading dilute media and freshwater, evolutionary pressures may have selected for rapid response mechanisms like anisosmotic extracellular regulation to the detriment of much slower responses like isosmotic intracellular regulation.

Glycine, proline, alanine and arginine are the main effectors of intracellular isosmotic regulation in most crustaceans and constitute 40 to $60 \%$ of total FAA concentration, independently of salinity, ontogenetic stage or habitat (Dalla Via 1986, Freire et al. 1995, Haond et al. 1999, Huong et al. 2001, Wang et al. 2004, Augusto et al. 2007a,b). In Palaemon northropi, the decrease in muscle total FAA on acclimation to $5 \%$ is mainly a consequence of diminished glycine, arginine and proline, confirming that these nitrogenous components play a significant role in regulating intracellular volume. The 1.5 -fold increase in hemolymph total FAA concentration after $5 \mathrm{~d}$ at $5 \%$ may derive from FAA efflux from the muscle tissue. Investigations in Eriocheir sinensis (Gilles 1977), Panulirus japonicus (Shinagawa et al. 1995) and E. japonicus (Abe et al. 2002) reveal that hemolymph FAA increase on exposure to dilute media and may be stored as hemolymph proteins like hemocyanin (Mantel \& Farmer 1983), which may increase the amount of oxygen available to cells (Gilles \& Péqueux 1981).

Our data confirm that FAA concentrations in muscle tissue constitute an effective parameter to evaluate the degree of adaptation to dilute media. FAA titers were higher in Palaemon northropi than in diadromous freshwater palaemonids like Macrobrachium amazonicum and $M$. olfersi (164 and $188 \mathrm{nmol} \mathrm{mg}^{-1} \mathrm{DW}$, respectively; Augusto et al. 2007a) and M. rosenbergii ( 390 nmol mg-1 DW; Huong et al. 2001). Further, in $M$. brasiliense, a hololimnetic inhabitant of inland continental rivers that exhibits abbreviated larval development, FAA concentrations (142 nmol mg ${ }^{-1}$ DW) are lower than in other Macrobrachium species (Faria et al. 2008). FAA concentrations in P. northropi muscle may thus be similar to those of ancestral marine palaemonids. Although part of a separate clade, P. northropi is a more basal species than many sympatric Macrobrachium species (Murphy \& Austin 2005).

The capability to adjust survival limits to changing environmental salinities would be of immense adaptive value during the evolutionary invasion of freshwater. The euryhaline intertidal shrimp Palaemon northropi exhibits many physiological adaptations such as efficient short-term hypo- and hyperosmotic and ionic regulation, rapid acclimation to salinity change and elevated yet labile muscle FAA concentrations, all of which are well suited to underpin the conquest of dilute media. This mosaic of characteristics suggests that the physiology of $P$. northropi and similar species may be crucial to understanding the invasion of dilute media by ancestral marine crustaceans many millions of years ago.

Acknowledgements. This investigation constitutes part of a $\mathrm{PhD}$ dissertation submitted by A.A. to the postgraduate program in Comparative Biology, and an undergraduate course-conclusion monograph presented by A.S.P. to the Department of Biology, FFCLRP, Universidade de São Paulo (USP). Research was partially financed by grants from FAPESP (no. 96/01842-8) and Pronex (no. 66/1132/98-6) to L.J.G. A.A. and A.S.P. received scholarships from FAPESP (nos. 01/00576-2 and 01/01763-5, respectively) and J.C.M. from CNPq (no. 303282-84). Shrimp were collected under permit no. 18/2002 issued by the Instituto Brasileiro do Meio Ambiente e dos Recursos Naturais Renováveis. The Centro de Biologia Marinha, USP, provided logistic support during collection expeditions.

\section{LITERATURE CITED}

Abe H, Okuma E, Amano H, Noda H, Watanabe K (2002) Distribution, metabolism and physiological functions of free d-amino acids in aquatic invertebrates. Nippon Suisan Gakkaishi 68:516-525

Augusto AS, Greene LJ, Laure H, McNamara JC (2007a) The ontogeny of isosmotic intracellular regulation in the diadromous, freshwater palaemonid shrimps, Macrobrachium amazonicum and $M$. olfersi (Crustacea, Decapoda). J Crustac Biol 27:626-634

Augusto AS, Greene LJ, Laure H, McNamara JC (2007b) Adaptive shifts in osmoregulatory strategy and the invasion of fresh water by brachyuran crabs: evidence from Dilocarcinus pagei (Trichodactylidae). J Exp Zool A 307: 688-698

> Belli NM, Faleiros RO, Firmino KCS, Masui D, Leone FA, McNamara JC, Furriel R (2009) Na,K-ATPase activity and epithelial interfaces in gills of the freshwater shrimp Macrobrachium amazonicum (Decapoda, Palaemonidae). Comp Biochem Physiol A 152:431-439

Biagini GA, Kirk K, Schofield PJ, Edwards MR (2000) Role of $\mathrm{K}^{+}$and amino acids in osmoregulation by the free-living microaerophilic protozoon Hexamita inflate. Microbiology 146:427-433

> Bidlingmeyer BA, Cohen SA, Tarvin TL, Frost B (1987) A new, rapid, high sensitivity analysis of amino acids in food type sample. J Assoc Off Anal Chem 70:241-247

Born JW (1968) Osmorregulatory capacities of two caridean shrimps, Syncaris pacifica (Atydae) and Palaemon macrodactylus (Palaemonidade). Biol Bull 134:235-244

Campbell PJ, Jones MB (1989) Osmoregulation of the estuarine prawn Palemon longirostris (Caridea: Palaemonidae). J Mar Biol Assoc U K 69:261-272

Charmantier G, Anger K (1999) Ontogeny of osmoregulation in the palaemonid shrimp Palaemonetes argentinus (Crustacea: Decapoda). Mar Ecol Prog Ser 181:125-129

Dalla Via GJ (1986) Salinity responses of the juvenile penaeid shrimp Penaeus japonicus. II. Free amino acids. Aquaculture 55:307-316

> Denne LB (1968) Some aspects of osmotic and ionic regulation in the prawns Macrobrachium australiense (Holthuis) and M. equidens (Dana). Comp Biochem Physiol 26:17-30

Edwards HA (1982) Free amino acids as regulators of osmotic pressure in aquatic insect larvae. J Exp Biol 198:153-160 
Faria SC, Augusto AS, McNamara JC (2008) Regulação anisosmótica extra- e isosmótica intracelular no camarão hololimnético de água doce Macrobrachium brasiliense (Decapoda, Palaemonidae). V Congresso Brasileiro sobre Crustáceos, 10-13 Nov 2008, Gramado, Brazil. Available at www.vcbc.com.br/trabalhos/imprimir_trabalhos.asp?ID $=103$ (Abstract)

Fidhiany L, Kijima A, Fujio Y (1991) Adult salinity tolerance and larval salinity requirement of the freshwater shrimp Palaemon paucidens in Japan. Tohoku J Agric Res 42: $17-24$

- Freire CA, McNamara JC (1995) Fine structure of the gills of the freshwater shrimp Macrobrachium olfersii (Decapoda): effect of acclimation to high salinity medium and evidence for involvement of the lamellar septum in ion uptake. J Crustac Biol 15:103-116

Freire CA, Rosa JC, McNamara JC, Greene LJ (1995) Neuroendocrine control of osmotic regulation in the freshwater shrimp Macrobrachium olfersii (Wiegmann) (Crustacea, Decapoda): free amino acid concentrations in the hemolymph. Gen Comp Endocrinol 100:83-91

Freire CA, Cavassin F, Rodrigues EN, Torres AH Jr, McNamara JC (2003) Adaptive patterns of osmotic and ionic regulation, and the invasion of fresh water by the palaemonid shrimps. Comp Biochem Physiol A 136:771-778

Freire CA, Onken H, McNamara JC (2008) A structurefunction analysis of ion transport in crustacean gills and excretory organs. Comp Biochem Physiol A 151:272-304

Frick NT, Wright PA (2002) Nitrogen metabolism and excretion in the mangrove killifish Rivulus marmoratus. 1. The influence of environmental salinity and external ammonia. J Exp Biol 205:79-89

Gilles R (1977) Effects of osmotic stresses on the proteins concentration and pattern of Eriocheir sinensis blood. Comp Biochem Physiol 56:109-111

Gilles R, Péqueux A (1981) Cell volume regulation in crustaceans: relationship between mechanisms for controlling the osmolality of extracellular and intracellular fluids. J Exp Zool 215:351-362

Gilles R, Péqueux A (1983) Interactions of chemical and osmotic regulation with the environment. In: Bliss DE, Vernberg FJ, Vernberg WB (eds) The biology of Crustacea, Vol 8. Enviromental adaptations. Academic Press, New York, p 109-117

> González-Ortegón E, Pascual E, Cuesta JA, Drake P (2006) Field distribution and osmoregulatory capacity of shrimps in a temperate European estuary (SW Spain). Estuar Coast Shelf Sci 67:293-302

Haond C, Bonnal L, Charmantier G, Trilles JP (1999) Ontogeny of intracellular isosmotic regulation in the European lobster Homarus gammarus. Physiol Biochem Zool 72: $534-544$

Holthuis LB (1952) A general revision of the Palaemonidae (Crustacea, Decapoda, Natantia) of the Americas. II. The subfamily Palaemoninae. Allan Hancock Occas Pap 12: $1-136$

Huong DTT, Yang WJ, Okuno A, Wilder MN (2001) Changes in free amino acids in the hemolymph of giant freshwater prawn Macrobrachium rosenbergii exposed to varying salinities: relationship to osmoregulatory ability. Comp Biochem Physiol A 128:317-326

> Jalihal DR, Sankolli KN, Shenoy S (1993) Evolution of larval development patterns and process of freshwaterization in the prawn genus Macrobrachium Bate, 1868 (Decapoda, Palaemonidae). Crustaceana 65:365-376

> Kirkpatrick K, Jones MB (1985) Salinity tolerance and osmoregulation of a prawn, Palemon affinis. Milne Edwards
(Caridea: Palaemonidae). J Exp Mar Biol Ecol 93:61-70

Kirschner LB (2004) The mechanism of sodium chloride uptake in hyperregulating aquatic animals. J Exp Biol 207: 1439-1452

Lee CE, Bell MA (1999) Causes and consequences of recent freshwater invasions by saltwater animals. Trends Ecol Evol 24:284-288

Leone FA, Masui D, Mantelatto F, Furriel R, McNamara JC (2005) $(\mathrm{Na}, \mathrm{K})$-ATPase from crustacean gill microsomes: a molecular marker to evaluate adaptations to biotopes of different salinities. Trends Comp Biochem Physiol 11:1-15

Lima AG, McNamara JC, Terra WR (1997) Regulation of hemolymph osmolytes and gill $\mathrm{Na}^{+} / \mathrm{K}^{+}$-ATPase activities during acclimation to saline media in the freshwater shrimp Macrobrachium olfersii (Wiegmann, 1836) (Decapoda, Palaemonidae). J Exp Mar Biol Ecol 215:81-91

Mantel LH, Farmer LL (1983) Osmotic and ionic regulation. In: Bliss DE, Mantel LH (eds) The biology of Crustacea, Vol. 5. Internal anatomy and physiological regulation. Academic Press, New York, p 53-61

- McNamara JC, Lima AG (1997) The route of ion and water movements across the gill epithelium of the freshwater shrimp Macrobrachium olfersii (Decapoda, Palaemonidae): evidence from ultrastructural changes induced by acclimation to saline media. Biol Bull 192:321-331

McNamara JC, Torres AH (1999) Ultracytochemical location of $\mathrm{Na}^{+} / \mathrm{K}^{+}$-ATPase activity and effect of high salinity acclimation in gill and renal epithelia of the freshwater shrimp Macrobrachium olfersii (Crustacea, Decapoda). J Exp Zool 284:617-628

McNamara JC, Rosa JC, Greene LJ, Augusto A (2004) Free amino acid pools as effectors of osmotic adjustment in different tissues of the freshwater shrimp Macrobrachium olfersii (Crustacea, Decapoda) during long-term salinity acclimation. Mar Freshw Behav Physiol 37:193-208

> Mendonça NN, Masui D, McNamara JC, Leone FA, Furriel R (2007) Long-term exposure of the freshwater shrimp Macrobrachium olfersii to elevated salinity: effects on gill $\left(\mathrm{Na}^{+}, \mathrm{K}^{+}\right)$-ATPase alpha-subunit expression and $\mathrm{K}^{+}$-phosphatase activity. Comp Biochem Physiol A 146:534-543

> Moreira GS, McNamara JC, Shumway SE, Moreira PS (1983) Osmoregulation and respiratory metabolism in Brazilian Macrobrachium (Decapoda, Palaemonidae). Comp Biochem Physiol 74:57-62

Morris S, Taylor AC, Bridges CR (1988) Response of haemolymph oxygen affinity to simultaneous salinity and oxygen stress in the intertidal prawn, Palemon elegans (Rathke). Comp Biochem Physiol A 90:31-39

Murphy N, Austin CM (2005) Phylogenetic relationships of the globally distributed freshwater prawn genus Macrobrachium (Crustacea: Decapoda: Palaemonidae): biogeography, taxonomy and the convergent evolution of abbreviated larval development. Zool Scr 34:187-197

Onken H, McNamara JC (2002) Hyperosmoregulation in the red freshwater crab Dilocarcinus pagei: structural and functional asymmetries of the posterior gills. J Exp Biol 205:167-175

Parry G (1954) Ionic regulation in the palaemonid prawn Palaemon (=Leander) serratus. J Exp Biol 31:601-603

Péqueux A (1995) Osmotic regulation in crustaceans. J Crustac Biol 15:1-60

Pereira G, Garcia A (1995) Larval development of Macrobrachium reyesi Pereira (Decapoda: Palaemonidae), with a discussion on the origin of abbreviated development in palaemonids. J Crustac Biol 15:117-133

Potts WTW, Parry G (1964) Sodium and chloride balance in the prawn Palaemonetes varians. J Exp Biol 41:591-601 
Roesljadi G, Anderson JW, Petrocelli SR, Giam CS (1976) Osmoregulation of the grass shrimp Palaemonetes pugio exposed to polychlorinated biphenyls (PCBs). I. Effect on chloride and osmotic concentrations and chloride- and water-exchange kinetics. Mar Biol 38:343-355

Ruppert EE, Barnes RD (1994) Invertebrate zoology. Harcourt Brace College Publishers, Fort Worth, TX

Sandifer PA, Hopkins JS, Smith T (1975) Observations on salinity tolerance and osmoregulation in laboratory-reared Macrobrachium rosenbergii post-larvae. Aquaculture 6:103-114

Schales O, Schales SS (1941) A simple and accurate method for the determination of chloride in biological fluids. J Biol Chem 140:878-883

Schubart CD, Diesel R (1998) Osmoregulatory capacities and penetration into terrestrial habitats: a comparative study of Jamaican crabs of the genus Armases Abele, 1992 (Brachyura: Grapsidae: Sesarminae). Bull Mar Sci 62: 743-752

Schubart CD, Diesel R (1999) Osmoregulation and the transition from marine to freshwater and terrestrial life: a comparative study of Jamaican crabs of the genus Sesarma. Arch Hydrobiol 145:331-347

Shinagawa A, Suzuki T, Konosu S (1995) Preliminary studies on the effects of salinity on intracellular nitrogenous osmolytes in various tissues and hemolymph of the Japanese spiny lobster, Panulirus japonicus (Von Siebold, 1824).

Editorial responsibility: Victor Benno Meyer-Rochow, Bremen, Germany
Crustaceana 68:130-137

Spaargaren GH (1972) Osmoregulation in the prawns Palaemon serratus and Lysmata seticaudata from the Bay of Naples. Neth J Sea Res 5:416-436

> Tan CH, Choong KY (1981) Effect of hyperosmotic stress on hemolymph protein, muscle ninhydrin positive substances and free amino acids in Macrobrachium rosenbergii (de Man). Comp Biochem Physiol 70:485-489

Taylor HH, Taylor EW (1992) Gills and lungs: the exchange of gases and ions. In: Harrison FW, Humes AG (eds) Microscopic anatomy of invertebrates. Decapod Crustacea, Vol 10. Wiley-Liss, New York, p 203-293

Thurman C (2003) Osmoregulation by six species of fiddler crabs (Uca) from the Mississippi delta area in the northern Gulf of Mexico. J Exp Mar Biol Ecol 291:233-253

Tsai JR, Lin HC (2007) V-type $\mathrm{H}^{+}$-ATPase and $\mathrm{Na}^{+}{ }^{+} \mathrm{K}^{+}$-ATPase in the gills of 13 euryhaline crabs during salinity acclimation. J Exp Biol 210:620-627

Wang WN, Wang AL, Bao L, Wang JP, Liu Y, Sun RY (2004) Changes of protein-bound and free amino acids in the muscle of the freshwater prawn Macrobrachium nipponense in different salinities. Aquaculture 233:561-571

Weihrauch D, McNamara JC, Towle DW, Onken H (2004) Ion-motive ATPases and active, transbranchial $\mathrm{NaCl}$ uptake in the red freshwater crab Dilocarcinus pagei (Decapoda, Trichodactylidae). J Exp Biol 207:4623-4631

Submitted: May 18, 2009; Accepted: August 17, 2009

Proofs received from author(s): October 16, 2009 